CHAPTER TWO

\title{
SKETCHING OUT AN EMANCIPATORY DISCOURSE: CORRUPTION, POLITICAL SPACES AND SOCIAL IMAGINARIES
}

\begin{abstract}
Here, then, is the paradox in the search for civil society at the century's end. The very fertility of the Idea-its broad, transnational appeal as a trope of moral imagining-stems from its polyvalence: its capacity to condense distinct doctrines and ethical strains in a fan of pliable associations that can be variously distilled and infinitely elaborated [...]. The more inchoate and polymorphous, the more appealing: the more appealing, the less attainable in any substantive, meaningful form. [...]. As Durkheim said long ago, the ritual of conjuring with resonant signs is a condition of the very possibility of imagining society, sui generis. ${ }^{1}$

But if there is no ground of the social, any historical intervention will be the work of limited historical agents. This limitation, however, is more than compensated for by a new freedom that social agents win as they become the creators of their own world. ${ }^{2}$
\end{abstract}

\section{Introduction}

After having set the backdrop with an elaboration of the development discourse of corruption, on the one hand, and the scholarly discourse of corruption, on the other hand, the purpose of this chapter is to set up the main stage, namely to outline a specifically political theory of corruption. To tackle this rather ambitious undertaking, however, some conceptual and theoretical illuminations are required. In this chapter I will argue that the scholarly and the development discourse on corruption are intimately intertwined and create a particular, dominant body of knowing and acting upon corruption in Africa. This argument, however, will not serve to underpin similar arguments about the discourse of governance, i.e. that it has inherently repressive effects, intentionally or unintentionally, in that it consolidates unaccountable and unresponsive power relations on a domestic and international level. ${ }^{3}$ There is a strong and well-documented case for such an argument, but my prime research interest leads to an

1 See Comaroff/Comaroff 1999: 6.

2 See Laclau 1996: 102-103.

3 For such a narrative see, for instance, Marquette 2003 or Harrison 2004. 
inversion of this angle: my enquiry is driven by the quest to explore the fields and processes of social transformations that the discourse of corruption opens up, rather than a quest for the spaces it closes down. This is, evidently, a fundamentally different approach to the development discourse on corruption, which seeks to identify and redress 'dysfunctions'. It is also a fundamentally different approach to the scholarly discourse on corruption, which essentially refers, optimistically or fatalistically, to the importance of ruled-based, meritocratic behaviour, institutions and norms. My critique is that that both discourses obscure processes of change that do occur. The development discourse does this by its myopic and technocratic rationale, breaking 'politics' down into standardised, operational procedures, indicators and projects. The academic discourse, albeit on a more sophisticated level, does this by its ultimate reference to social theories derived from specific historical Western experiences. This leads to patterns demarcating the absence of similar processes or conditions visible in African societies, rather than illuminating the presence of actors, processes and conditions in Africa which are conducive to democratising and emancipatory spaces and structures. The body of literature since Foucault has given ample demonstrations of the mechanisms and micro-mechanisms through which discourses shape power relations and social realities. But it seems that we need a very different set of lenses to discover changes that are effected in a different direction, changes that may be of a more progressive-in a political sense of liberating and emancipatory nature.

But before such processes can be analysed on an empirical level in a way that does not replicate the blind spots of existing discourses, some central theoretical challenges need to be addressed. In particular, five conceptual steps are required, which will be undertaken in this chapter:

Firstly, a theoretical frame of reference shall be developed that enables us to identify within the discourse of corruption the political and social spaces that open up through the contact and interaction with the discourse (Section 2, below). For as the closing thoughts of the previous chapter indicated, my hypothesis is that such transformative processes are both more incremental as well as more political than inscribed in the discourse(s) of corruption-hence their invisibility. To grasp such emancipatory process adequately, a completely different theoretical approach is required, one which formulates a political theory that is linked to political practice. In particular, it needs to incorporate the mechanisms and regularities of political articulations whilst at the same time doing justice to the openings and transformations of social agency and political orders; in other 
words, not to apply a theory that does not 'smother' the incremental processes of social and political transformation, but to develop a conceptual framework that profiles the interrelationship between social agents and political discourses and renders the dynamics of change effected by such interrelationships legible. Such a theory is found in post-Marxist political theories. Hence, in this second step, a political discourse theory will be outlined, drawing heavily on the political theory of Ernesto Laclau. His political theory will serve as the central theoretical frame of reference to identify and analyse what I am boldly (and in reference to post-Marxism) calling emancipatory processes in the classic sense of 'setting free'. ${ }^{4}$ This will enable me to carve out central concepts and their relevance to an analysis of corruption and political spaces in Africa. Rather than generalisations from a closed theoretical paradigm of 'Africa' or 'African politics', which characterise more recent theories discussed in the previous chapter, for my purpose a general theory on politics, or rather: the political is required. ${ }^{5}$ This reconceptualisation is not only tapered towards identifying sites of social and political agency, it puts such operations at the very centre of the theoretical inquiry. In particular, I shall argue that "corruption" is not so much a practice or structural feature, but rather a nodal point which enables different claims, interests and identities to link up and structure the political in new ways. Corruption is, in the terms of political discourse theory, an 'empty signifier', a catalyst of social and political organisation. Key here is not so much what corruption 'is', key here is the ways in which different actors relate to what 'corruption' signifies and the ways the seek to differentiate or link up in relation to this signifier. My key hypothesis is that the very discourse of corruption provides the terrain in which these struggles take place. The overarching interest and the main objective of the following chapters is, consequently, the exploration of the political and social spaces that 'corruption' opens up (or closes down), i.e. the manifold political and social articulations that feed off corruption as a reference. My premise is that although the discourse of corruption may take on a hegemonic (in the sense of dominating) shape, it actually provides the terrain for the articulation of particular struggles - and

4 The Concise Oxford Dictionary defines emancipation as "setting free, esp. from slavery or from legal disabilities", but also as "setting free, freedom, from intellectual or moral fetters" (Fowler/Fowler 1951: $387-388$ ), putting freedom and liberation at the heart of the term. The term emancipation will be elucidated more thoroughly in the following sections.

${ }^{5}$ For an interesting contribution exploring the differences of the political and politics in discourse theory, see Dyrberg 2004. 
potentially may lead to the creation of a plurality of political spaces and public spheres.

Equipped with these more refined analytical tools, it then becomes possible to illuminate actors and practices in the context of corruption that shed more light on their transformational potential. However, in addition to developing a more nuanced conceptual framework to analyse such politics, two key spheres of society need to be explored in more detail. If the state is and remains the central reference point of the discourse of corruption in Africa, surprisingly little is being said about the two other classic social spheres, namely civil society and the economy-although the discourse of corruption rides on the back of loaded implications about these two key non-state spheres and their relationship to the state, or, more broadly, to trajectories of development. In implicit or explicit reference to Western trajectories, both these spheres carry with them promise of democracy and wealth, promise of nurturing and enabling the kind of political and economic spaces that are seen to be prerequisite for overcoming the 'institutional dysfunctions' or 'infernal mechanisms' leading to corruption. Simultaneously, civil society and the private sector, like the strong state, are mainly present in the discourse through their identified absence. In an attempt to systematically explore the potential spaces for political mobilisation and change, hence, these two societal spheres and their relevance for the discourse of corruption, or more concretely: for the transformation of society to a more democratic society shall be explored. So, secondly, the loaded concept of civil society shall be scrutinised (Section 3, below). I shall fleetingly dwell on the normative blinkers that its use conventionally implies, but, against the backdrop of post-Marxist theory, primarily seek the liberating social imaginaries that the concept conveys and enables.

Thirdly, then, I shall turn to the economy, a field producing and reproducing key societal power relations, defining access to and control over both economic as well as social resources (Section 4, below). Historically, the social classes emerging from the development of a private sector have been pivotal to the separation between the private and public sphere, to the primacy of the rule of law, and the kind of political accountability structures which are manifest in all shades of liberal democracy. As such the state of the private sector is intimately linked to the state of civil society, both of which in turn frame the state of the state - and all of which are, as I shall argue, primarily conceived in the discourse on corruption via their deficiency, if not outright absence in Africa. And yet, the discourse relies heavily on the idea of a structural transformation that is both cause 
and consequence of the intentional activities of such social classes, in particular of the middle class. Organised interests of the middle class have historically and epistemologically been of paramount importance. They signify a (part of) society that is not ascriptively defined, but is individualised and economically autonomous, which defines its societal linkages via economic and political interests and a particular professional ethos rather than via familial or patronage ties (Section 5 , below). Their importance for a particular 'modern' trajectory and social imaginary shall be carved by illuminating the role of professional associations in sociological theories on social change-but more significantly, by discussing their role and presence in contemporary African societies (Section 6).

This chapter, as a whole, will set the scene for the empirical investigation of the discourse of corruption as appropriated by professional associations in Tanzania in the next chapter.

\section{Reinserting Politics: A Political Theory of Corruption}

My starting-point is the catch-all nature of the term corruption that has been critiqued so sharply with regard to the development discourse. The catch-all, however, also applies to the scholarly discourse, where 'corruption' denotes a plethora of values, practices and structures that, ultimately, undermine the spirit of fruitful development. I will argue that conceivably there is a certain political productivity in this 'emptiness' of the term. Its very amorphousness allows for different actors to employ it and connect to each other: using 'corruption' and the seemingly universal meanings it conveys as a vehicle to articulate and negotiate different visions of values, norms, rationales, interests, and not least visions. How else would social actors from different social spheres, positions and life-worlds communicate, if not on the back of a term that allows for all different meanings and interests to be transported and articulated? What I intend to do here is seek to explore on a theoretical level the articulations that are resonated in the very hollowness of the term corruption. Ultimately, my intention is to identify the emancipatory and democratising discourses that its very malleability render possible.

Drawing on post-Marxist theory, the argument developed here is that the term corruption is an 'empty signifier': a chronically underdefined term (such as justice, or freedom) that has no fixed signified, and hence can be filled with contingent meaning. This filling of meaning is far from arbitrary-it serves an essential systemic function. The argument is 
elaborated extensively in the works of Laclau and fellow scholars, ${ }^{6}$ who theorise the discursive formations of emancipatory spaces in a novel way. Conventionally, discourses construct meanings and subjects, and seek to represent universally valid truths. In ordinary language use as well as in post-modern usage the term discourse has been implicitly or explicitly linked to the concept of hegemony, a state of political and symbolic supremacy, of the blanketing out of difference, and hence of repression and domination. ${ }^{7}$ Laclau has provided a highly sophisticated reformulation of the concept of discourse, that, based on a Gramscian understanding of hegemony, loses its a priori connotation with repression inherent in much Foucauldian thought. On the contrary, in Laclau's approach discourses and hegemonising operations become central to the constitution of society-in particular to democratic societies. In this thrust, Laclau and his fellow thinkers have contributed to a radical reformulation of the relation between the 'universal' and the 'particular' - central categories of post-structuralist as well as post-modernist theories. A central theoretical innovation in post-Marxism is that there is no theoretical bias of the particular over the universal (in the sense of a 'politics of difference'); on the contrary, the dual reference to both the universal and the particular become constitutive of social and political life.

To understand his conceptualisation of hegemony this relationship between universalisation and particularism needs to be laid out more carefully. The basic premise Laclau develops is that any concept of the 'universal', i.e. articulations of 'unity' or 'wholeness', is an impossibility. The universal is a signifier, which implicitly or explicitly negates a system of difference. At the same time there is no universal claim which can wholly and truly eliminate all differences; it is a logical impossibility that a particular identity, constituted through difference, can fully represent all identities. ${ }^{8}$ In other words, universal claims are always expressions of

${ }^{6}$ I shall concentrate on Laclau's political theory, although his work developed and develops in close collaboration and critical interaction with the work of Mouffe 1993; 1996, Zizek 1990; 2000a; 2000b; 2000c, and Butler 2000a; 2000b; 2000c.

7 For an overview see Howarth 2000.

8 Here the intellectual engagement with post-structuralists as well as Marxism is evident; the former especially with the centrality of disagreement in politics as a central feature. As Norval expands: "The centrality given to disagreement in the post-structuralist theorization of democracy arises directly from one of its basic ontological presuppositions, namely, the 'impossibility of closure' of any identity or structure. This is important, for it affects the status of disagreement in the model, making it not only an empirical feature of political life, but something arising from a constitutive characteristic of modern society. [...] While society can relate to itself only on the condition that it forges a representation 
particular identities, never of a 'fullness' which exists and speaks for itself. A key universalism, namely, 'society' or the 'the social' is at the centre of Laclau's analysis. He argues that the notion of 'society' is a priori empty, it is an 'absent fullness', for the existence of 'a society' would imply the cancelling out of all differences. The term 'society' is thus more aptly conceptualised as a symbol representing such an absent fullness, a closed universality. This symbol, however, rather than having a meaning or a substance to itself, is filled with particularities, which have temporarily managed to symbolise universalities. But this appropriation of the universal through particularities is not a priori threatening or repressive, as implied in other discourse theories. On the contrary, a notion of universality is indispensible for any constitution of the social and the political. ${ }^{9}$ As Laclau argues: "The universal is an empty place, a term which can be filled with only by the particular, but which, through its very emptiness, produces a series of crucial effects in the structuration/destructuration of society" (Laclau 2000a: $5^{8}$ ). He goes on to argue that "the impossibility of a universal ground does not eliminate its need: it just transforms the ground into an empty place which can be partially filled in a variety of ways (the strategies of this filling is what politics is about)" (Laclau 2000a:59). In other words, such terms and imaginaries that can impossibly be 'fixed' as one particular signifier are constitutive for social and political processes, for constituting society as such: for political struggles, contentions, and linkages around the 'filling', the definition of such signifiers are the very operations which enable different actors and identities to articulate and shape a common horizon which constitutes as an entity beyond their particularities.

Here enters Laclau's reconceptualisation of hegemony, for such a universality or common horizon, which is a necessary precondition for the

of its unity, these representations are secondary accretions $[\ldots]$. The moment of the institution of a social order is thus always already that of a particular imaginary regime" (Norval 2004: 152). See also Lefort 1986 for further elaborations on the role of Marxism in exposing the illusion of a society that accounts for itself.

9 As Laclau/Mouffe elaborate with respect to the idea of unity: "For, even though impossible, this remains a horizon, which, given the absence of articulation between social relations, is necessary in order to prevent an implosion of the social and an absence of any common point of reference. This unravelling of the social fabric caused by the destruction of the symbolic framework is another form of the disappearance of the political. In contrast to the danger of totalitarianism, which imposes immutable articulations in an authoritarian manner, the problem here is the absence of those articulations which allow the establishment of meaning common to the different social subjects" (Laclau/Mouffe 1985: 188). 
very emergence and maintenance of social relations, is constructed by discourses. In Laclau's terminology, universal references are constructed by hegemonic articulations, i.e. the articulation of particularistic identities that claim to embody some universal representation. ${ }^{10}$ Hence his reformulation of 'discourse' to 'hegemonic representation', ${ }^{11}$ which allows for a non-deterministic conceptualisation of hegemony: the universal can only be thought in specific social and political terms, capturing particularistic, contextualised articulations rather than essentialist universalisms. In a critical reformulation of Gramsci's theory, ${ }^{12}$ these discourses thus need to be constructed in a way that go beyond their particularistic interest to become intelligible to other social agents; for if only particular social identities exist, then the existence or emergence of "common point of reference", a "meaning common to the different social subjects" (Laclau/ Mouffe 1985: 188) elaborated above is not self-evident.

The mechanism through which this universalising effect of hegemonic representations is achieved is through the production of empty signifiers. ${ }^{13}$ Empty signifiers allow a discourse to be filled with particularistic and potentially incommensurable contents whilst maintaining a universal representation. In this sense, empty signifiers are essential for creating linkages, in Laclau's terminology: for enabling chains of equivalence between differential and particularistic identities. To understand this aspect it is pivotal to take note of the crucial structuring effect that empty signifiers have on social practices and society as such. ${ }^{14} \mathrm{~A}$ good example of the structuring effects of an empty signifier is for instance the 'nation': the idea of the nation consists of a somehow unified identification of fundamentally different identities, e.g. of gender, ethnic, regional, political, and religious

10 In Laclau/Mouffe's early reading, social identity itself emerges out discursive constructions, which they term 'discursive articulations', i.e. practices which establish a relation among elements. One important feature of such discursive articulations is that the social identities themselves are modified as a result of the articulation (Laclau/Mouffe 1985: 105), a point to which we shall return in our empirical analysis. In his later work, Laclau distanced himself from the notion that social identity must always or necessarily be discursively constructed, by introducing a primary category of dislocation'.

11 Laclau/Mouffe capture one angle of 'hegemony' very beautifully in following quote: The space of hegemony is "a space in which bursts forth the whole conception of the social based upon an intelligibility which reduces its distinct moments to the interiority of a closed paradigm" (Laclau/Mouffe 1985: 93).

12 See Gramsci, in particular Section 2 "State and Civil Society" (Gramsci 2008: 206-275).

13 For a detailed discussion of the role of empty signifiers for politics see Laclau 1996a: $36-46$.

14 For a discerning discussion of the 'universal' see Gasché 2004: 17-34. 
groups. Although these particular identities are constituted through a logic of difference, they are able to connect through a chain of references $v i s-\grave{a}$-vis an overarching universality. In other words, 'the nation' becomes an empty signifier by representing a universal identity. The chain of equivalence constructed by the empty signifier 'the nation' obscures the differential identities, by referring to something which is beyond particularities. Through the nodal points produced by the empty signifier, such chains of equivalence allow for the construction of a common identityalbeit one which is logically impossible, as these differences can only be overcome on a purely representative level. This is what Laclau (2000a: 56 ) terms the "representation of an impossibility": the universal is an objective impossibility, it can only be constituted through particularistic representations. ${ }^{15}$ At the same time, the production of linkages to other identities, which cancel out the differences between the different identities, is a precondition for a particular discourse to constitute itself beyond the narrow boundaries of its own terrain. In conclusion, the very condition of a politics of difference (Laclau's critical appropriation of a central postmodernist term) is precisely the appeal to universal principles. ${ }^{16}$

15 To illustrate the mechanisms through which hegemonic relations work, Laclau invites us to consider following extreme situation of a radical disorganisation of the social fabric: "In such conditions - which are not far away from Hobbes' state of nature-people need an order, and the actual content of it becomes a secondary consideration. 'Order' as such has no content, because it only exists in the various forms it is actually realized, but in a situation of radical disorder 'order' is present as that which is absent; it becomes an empty signifier, as the signifier of that absence. In this sense, various political forces can compete in their efforts to present their particular objectives as those which carry out the filling of that lack. To hegemonize something is exactly to carry out this filling function. (We have spoken about 'order', but obviously 'unity', 'liberation', 'revolution', etcetera belong to the same order of things. Any term which, in a certain political context becomes the signifier of the lack, plays the same role). Politics is possible because the constitutive impossibility of society can only represent itself through the production of empty signifiers" (Laclau 1996a: 44).

16 For detailed elaboration see Laclau 1996. This theoretical reconceptualisation is a conscious distinction to the debates on multi-culturalism and the theories informing them. Laclau's central premise is that precisely the split within particularism and universalisation, i.e. the 'unfullfilled fullness' which universalities signify, is essential to particularisms if they hopes to assert itself beyond its own boundaries. So the double reference to the universal and the particular are the very stuff of social and political relations. Although he clearly recognises the dangers of universalising discourses and their potentially totalitarian effects, he argues that "the assertion of pure particularism, independently of any content and of the appeal to universality transcending it, is a self-defeating enterprise" (Laclau 1996: 26). I shall return to the role of particularism and radical democracy further down in this section. 
Empty signifiers thus frame the nodal points at which differential identities transcend their differences and collapse insofar as they refer to a common universality. Put differently, they relate to each other via the reference to a common universality, via an empty signifier. "There is no universality, as we have seen, except through an equivalence between particularities, and such particularities are always contingent and contextspecific" (Laclau 2000c: 211). In this way, empty signifiers are constitutive for the construction of social order, in fact for society as such. Particular identities require nodal points to relate to each other and enable this process of identification with the universal-here: the absent fullness of society. Empty signifiers provide this filling function. On centre stage here are the modes in which social demands (particularities) are translated into struggles or notions that take on a wider representation beyond their own, narrow identity. ${ }^{17}$ As Norval expounds, this process of constructing hegemony thus is in sharp relief from naked coercion or imposition of (particular) demands on subordinate groups, for it features a two-fold character:

On the one hand, demands are always specific, even particularistic, in that they arise from the experiences and conditions of particular and limited groups. On the other hand, for those demands to become universalized, to function as a horizon in which more generalized demands may become inscribed, they need to be marked by something transcending their particularity (Norval 2004: 157).

In other words, there is "both a contextual and a context-transcending dimension in the process of the hegemonization of a field of demands" (Norval 2004: 157). Such a universalisation of demands, manifested as political struggles, are only possible through the production of empty signifiers.

Although it clearly emerges from his conceptualisation of the 'contextual and context-transcending dimensions' of such hegemonic representations, Laclau is at pains to emphasise that the 'emptiness' to which he refers is a concrete notion. He exemplifies the steps connecting 'emptiness' with 'universality' by summing up his key arguments in a very illuminative way:

17 This double feature of hegemonic representations distinguishes the political theory of Laclau from the particularism and subjectivism that post-modern narratives on identities and interests are critiqued for. 
[Thus], universality, not being either the result of a conceptual abstraction or of a conceptually grounded telos, is simply a concrete historical construction and not an aprioristically determined presupposition of the social as such. The anti-globalization movement, for instance, attempts to construct equivalential chains between many locally based struggles and demands. In that way it breaks with the narrow particularism of the latter and universalizes them by presenting them as part of a wider emancipatory struggle. But this construction of the universal through equivalential inscription is a process of identification which - as all processes of identification-is not purely conceptual but involves a plurality of intellectual, political, and affective dimensions (Laclau 2004: 281). ${ }^{18}$

Important to note here is that such hegemonising representations do not leave the identities or interests of the participants unchanged. They necessarily involve an engagement by the social groups on all these different levels. As Laclau himself alludes to in above quote, the very discoursesand hence the social demands and identities represented-change as a result of the contingent hegemonising processes. This is a point I shall return to further down, and which will be particularly salient for the empirical case-studies.

Summing up, in Laclau's political theory hegemonic articulations, and by elongation the empty signifiers that act as transmittors beyond particularistic identities, have a strong emancipatory potential. They create the conditions of democratic politics, of the articulation of different social struggles. So empty signifiers, far from being meaningless, are the very mediums of political articulations and struggles. They fully embody the contradiction of the incommensurability between the universal and the particular, the 'constitutive lack' which never be fully transcended. But far from being a deficiency, this constitutive lack signifies the possibility of plural hegemonic formations: "Incompletion and provisionality belong to the essence of democracy" (Laclau 1996: 16). Hence, empty signifiers enable a crucial democratic moment, with no one project or one political will being irreversible or uncontestable. Quite the opposite: all hegemonic representations are subject to contingent processes of identification.

Before connecting Laclau's political theory to the discourse of corruption, a word on the conceptualisation of social agents is required. ${ }^{19}$

18 For case-studies discussing localised protest movements in the light of post-Marxist theory see Griggs/Howarth 2000, 2008.

19 As the elaborations in Laclau/Mouffe 1985 underline, much of this theoretical thrust derives from their intention to reject socialist universalism, which posits a necessary universal working class as the one and sole social agent, qua its economic position. 
Although agency seemingly disappears behind the central categories of the universal and the particular, the chains of equivalence and the hegemonic strategies transcending the split between universalism and particularism are shaped and driven by social agency. In fact, Laclau's core interest revolves around the question of how to empower identities and cultural differences in an emancipatory way, especially under the contemporary 'dislocatory' effects of globalisation. ${ }^{20}$ Unlike, for instance, in Foucauldian discourse theory, this political theory puts social agents on centre stage. Consistently, Laclau's and Mouffe's notion of a radical democracy is not only "to expand egalitarian effects into more and more areas of the social", but also to recognise that "the relative autonomy of the demands of different groups has to be accepted and articulated into a larger common movement, what is called 'a chain of equivalence'" (Critchley/Marchart 2004: 4). This prime consideration of plural social agents is what distinguishes this political theory from others, achieving a theorisation of social agency within a stringent framework of the social and society. Again in contradistinction to a Foucauldian discourse theory, where the notion of agency is smothered by a focus on discursive iterations, Laclau conceptualises social agents in an mediated fashion. His prime theoretical interest is the relationship between the universal and the particular, or more precisely: the political projects which aim to fill the "always receding horizon" (Laclau 1996: 34) of the universal with particular contents, which are connected by such chains of equivalence. But although the theory operates on a high level of abstraction, the 'contaminated' relationship between the particular and the universal is articulated as concrete political struggles by and between specific social agents:

If democracy is possible, it is because the universal has no necessary body and no necessary content; different groups, instead, compete between themselves to temporarily give to their particularisms a function of universal representation. Society generates a whole vocabulary of empty signifiers whose temporary signifieds are the result of political competition (Laclau 1996: 35).

In other words, political identities and interests shape and are shaped by contingent, historical processes of articulation. The more contestable and

20 The concept of 'dislocation' is a radical theorisation of Laclau's and Mouffe's notion of antagonism as the limit of the social; especially in Laclau 1990 and in his exchanges with Butler/Zizek 2000 dislocation becomes a primary category, capturing 'the outside' which is not necessarily discursively constructed in the form of an antagonism. For a more general discussion of the accelerated tempo of dislocatory experiences see Howarth 2000. 
the more reversible the 'fixing' of the meaning of signifieds is, the more democratic the society. This has major consequences on social agency, which in a democratic society is freed up to a wide and deep understanding of agentic possibility in relation to structural contexts. Paraphrasing Emirbayer and Mische, a democratic society brings forth and is brought forth by actors that see their worlds as more rather than less responsive to human imagination, purpose, and effort (cf. Emirbayer/Mische 1998: 973).

There are several key theoretical openings that this conceptualisation of social and political relations enables. First of all, as there are no logics of necessity which predetermine the composition of political identities or the outcome of political struggles, it allows a theoretical focus on the (de) construction of such political identities and interests. Second, as Norval argues, "it opens up a whole realm of theorization of social and political relations based on their contingent articulation" (Norval 2004: 155). And thirdly, it is a theory which, rather than seeking to eliminate the 'noise' of political struggles, puts tension and disagreement at the very heart of it, but without foreclosing the terrain for processes and procedures constructing consensus. ${ }^{21}$

Equipped with these theoretical keys I will unlock the enquiry of the following chapters. They are based on the central hypothesis that the discourse of corruption performs precisely such a filling function: 'corruption' provides various groups with the universal terrain to articulate their representations and to construct chains of equivalence. Corruption is an exceptionally attractive term by semantically denominating a deficiency, a lack of a particular kind of social order, and hence referring to that which is absent', to a particular, 'good' social order. However, the kind of order that is implied in the reference to corruption is widely different and in fact often incommensurable, although the semantics all refer to the same empty signifier: corruption as an obstacle to a level playing field' of the private sector, as a threat to 'the stability and security of societies', to 'the quality of life for all', and not least the 'values of democracy' - all of which are not necessarily compatible, or are even outright antagonistic notions. Professional associations, government officials, anti-corruption activists, grass-root organisations and CEOs of large international companies share neither the same lifeworld nor political agenda. So the rather puzzling fascination with corruption by actors from all (antagonistic)

${ }^{21}$ For a highly insightful discussion of and comparison between deliberative and postMarxist theories of democracy see Norval 2004, 2007. 
wakes of society suddenly makes sense when viewed through the lens of an empty signifier: different groups can and do seek to fill it with particular meanings and contents which further their own objectives. The signifier 'corruption' provides them with the frame of reference to connect these different identities and objectives, the chain of equivalence that cancels out incompatibilities between them, as well as providing the universal (one could also say: public) terrain for articulating particular interests and political struggles.

\section{Civil Society: The Omni-Present Absence in Africa}

Classically, the terrain of such democratic articulations and struggles has been analysed in the concept of civil society: the locus of empowered and articulate social groups actively engaging in shaping the state and creating a socio-political order which provides a mediating structure, not a structure of exclusion. It is to the emergence of independent, voluntary and organised representation of societal interests that such an ultimately fruitful relationship between state and society is pinned to. Hence, it comes as no surprise that throughout the discourse of corruption one mantra is chanted again and again: that the 'principal institutions of modern politics', ${ }^{22}$ the 'reform of public morals' ${ }^{23}$ or the 'secure and broad-based consensus on the rules of the political game'24 are the mediums as well as the products of social transformation that allow for rule-based, capable and legitimate collective action and representation.

The concept of civil society itself is based on the very idea of creating spaces for social actors to engage with the social foundations of the state. Conventionally defined, the realm of civil society lies between the primary units of society (individuals, families, clans, etc.) and the institutions of the state; ${ }^{25}$ civil society offers autonomous sources of social power, of

22 See Huntington 1969: 71.

23 See Olivier de Sardan 1999: 48.

${ }^{24}$ Leftwich 1993: 614; see also Hyden 1995; 1999.

25 Consider the working definition offered by Cohen/Arato in their seminal book on civil society and political theory, who consider civil society "as a sphere of social interaction between economy and state, composed above all of the intimate sphere (such as the family), the sphere of associations (especially voluntary associations), social movements, and forms of public communication. Modern civil society is created through forms of selfconstitution and self-mobilization. It is institutionalized and generalized through laws, and especially subjective rights, which stabilize social differentiation" (Cohen/Arato 1992: ix). Remarkable here is the explicit inclusion of the family, which is usually excluded, being a non-voluntary form of association. Important, however, is their inclusion of iterated forms 
specifically civic values and civic action, whilst opening up new opportunities of political life as a consequence of the pluralisation and differentiation of institutional life. Epistemologically the concept of civil society evolved from its specific relationship to the (Western) state: the idea and practice of a 'countervailing' force to the state, where social forces form an inherent part of the project of the nation state by engaging with the state and shaping the public sphere, thereby idealtypically signifying both a curtailing as well as empowering complement to the state. The concept of civil society evokes the representation and participation of social forces in the political realm, transforming the latter into a locus of civic identification and representation.

For pertinent geo-political reasons, the concept of civil society was rejuvenated again after the end of the Cold War, and has come to play a pivotal role in development discourse. The powerful effects of social movements and civic associations in bringing about political liberalisation of the Eastern European countries inspired hope and sharpened interest in their democratising role. Rather mockingly, Gellner describes this rediscovery in the following terms: "The dusty term, drawn from antiquated political theory, belonging to long, obscure and justly forgotten debates, re-emerged, suddenly endowed with a new and powerful capacity to stir enthusiasm and inspire action" (Gellner 1994: 5). In regard to Africa, the developmental potential of civil society became hugely influential, partly due to the collapsing economic and structural base of the state, partly due to the neo-liberal emphasis by international development agencies on private initiative. ${ }^{26}$

Many scholars have critiqued that the term civil society, as utilised in the current development discourse, is tenaciously and (more often

of public communication, which is, as will be discussed further down, an essential feature of civil society.

26 The sense of a politically democratising and also economically vibrant force is summed up perfectly by Gyimah-Boadi, who also alludes to the 'tabula rasa' with regard to the public sector that African societies faced after the severe economic crises of the 1970s: "However, some of that developmental potential of civil society was restored, by default or by design, following the near collapse since the late 1970 s of the African state and its economic development structures [...]. The proliferation of a wide range of grassroots and development NGOs in the 1980 s and 1990s was a key manifestation of this restoration. This phenomenon, combined with the growing emphasis on private sector development as well as the emergence of private sector development groups and revamping of business associations, present renewed possibilities for the development of the private sector and economic decentralization, which can only enhance the prospects of African democratic development in the twenty-first century." (Gyimah-Boadi 2004: 106). 
than not) blindly informed by the contemporary (neo)liberal ideology. ${ }^{27}$ Moreover, civil society plays a peculiarly double-edged role in development practice: on an ideological level, it is the locus of all that is empowering, equipped with the power to transform structural dysfunctions and check political predation; whilst on a functional level, it is looked upon as a service provider, a sector which can provide certain services that the state and the market are unable or unwilling to provide such services cost-efficiently, especially to marginalised groups. ${ }^{28}$ The purpose of this chapter is, however, not to deconstruct the discourse of civil society in development cooperation. The purpose of this chapter is to identify mediums and actors of social transformations creating political spaces and the kind of normative consensus that are prerequisite for political inclusion of an emancipatory nature, to seek the transformationary potential of civil society, the political spaces that social actors shape and create. For this it is necessary to explore the concept of civil society in greater detail, to peel out the core potential as a theoretical concept as well as a social force.

First and foremost: civil society cannot be thought without the state. Fundamentally, "civil society cannot be constituted as a truly separate instance, for its functions both anticipate and extend the state's role" (Laclau 2000a: 49). ${ }^{29}$ In liberal theory ${ }^{30}$ that informs much of the devel-

27 See, for instance, Comaroff/Comaroff 1999; Cohen/Arato 1994; Gellner 1996; Tester, 1992.

28 For pioneering critiques of the era on the role of NGOs and civil society in development see Edwards/Hulme (eds.) 1996 a, b. However, civil society has lost none of its allure for development cooperation. Consider for instance the Advisory Group on Civil Society and Aid Effectiveness (AG-CS), who emphasise that "civil society is inherently diverse, and CSOs fill a range of roles in social and economic development in any country, many of which are beyond those supported through official development assistance (ODA)" (AG-CS 2008: xiii). The Advisory Group draws particular attention to civil society's role in i) mobilising grassroots communities and poor or marginalized groups, ii) their monitoring role, iii) engaging in research and policy dialogue, iv) delivering services and programmes, iv) building coalitions, v) mobilising aid resources, and vi) civic education (AG-CS 2008: xiii).

29 On this point (perhaps only), there seems to be general consensus across social theory. Note, for instance, Giddens, who reformulates the relationship between state and civil society in terms of a contradiction: "The primary contradiction of the capitalist (nation-) state is to be found in the mode in which a 'private' sphere of 'civil society' is created by, but is separate from and in tension with, the 'public' sphere of the state. It is a mistake to suppose that everything that lies outside the scope of the state, if that is taken to mean institutions which precede, and are not incorporated within, the realm of state power. The origins of the modern state are also the origins of the sphere of civil society [...]. The capitalist state, as a 'socializing' centre representing the power of the community at large, is dependent on mechanisms of production and reproduction which it helps to bring into being but which are set of from and antagonistic to it" (Giddens 1984: 197).

30 For an elaboration of Marxist and post-Marxist perspectives on civil society see Laclau 2000a: 47-59. 
opment discourse, civil society is generally conceptualised in three ways: as a social sector counterbalancing the state, as a societal sphere that nurtures specifically civic values, or, in its most truncated form, as a collection of non-governmental organisations. This admittedly grossly reduced outline does indicate, however, that civil society is ab ovo conceived in relationship with the state: both in opposition to the state, confining the state's hegemonic (here: in the sense of dominant and appropriating) tendencies, as well as complementing the state, weaving a social fabric that enhances and supports public institutions. ${ }^{31}$ Historically, the concept of civil society emerged as a signifier for the separation of state and society, for the divide between the public (i.e. state institutions) and the private (i.e. the realm of citizens). The realm of civil society is defined by civic practices, identifying with the values of liberal capitalist order. ${ }^{32}$

Gellner, interested primarily in the conditions of liberty of modern society, emphasises the buffering role of civil society against state dominance:

The simplest, immediate and intuitively obvious definition, which also has a good deal of merit, is that Civil Society is that set of diverse non-governmental institutions which is strong enough to counterbalance the state and, while not preventing the state from fulfilling its role of keeper of the peace and arbitrator between major interests, can nevertheless prevent it from dominating and atomizing the rest of society (Gellner 1994: 32).

Conventionally, such civic groups encompass different types of voluntary organisations, whose common denominator is the representation collective interests of both a political as well as non-political nature-innocuous ones such as sports clubs or community organisations, to more overtly political such as trade unions and professional associations, and not least newer forms of issue-based organisations, such as human rights or environmental organisations.

However, not all voluntary or non-profit social organisations are subsumed under civil society, as Chazan emphasises with a specific focus on African societies:

Not all social forces are part of civil society [...]. Civil society is separate from the state but relates to the state: parochial associations that do not evince an interest beyond their immediate concerns, groups that do not have a

31 For a detailed discussion on the history and conceptual schools of the term civil society see Cohen/Arato 1992, Gellner 1994 or Elliott 2003.

32 See, for instance, Putnam and his fellow authors (1993) on the importance of 'civic values'. 
concept of the state beyond their own aims, and those totally controlled by state agencies are excluded from its domain (Chazan 1994: 256).

In other words, a particular kind of civic attitude and value structure are required for civil society, indicating just how intimately the idea and practice of civil society is tied to specific Western conditions of socio-political transformations. ${ }^{33}$ The concept of 'civil society' is tied to the notion of 'civility', which Shils (1991) circumscribes as a particular social moral (or, in his words: the fundamental virtue of civil society): the recognition a common good, of individual rights and dignity beyond one's own community or family, and a sense of collective responsibility that restrains and mediates relations between members of society. This particularly civil 'virtue' or moral is underpinned by specific structural transformations, as Mamdani (1996) argues:

With an end to extra-economic coercion, force ceased to be a direct arbiter in day-to-day life. Contractual relations among free and autonomous individuals were henceforth regulated by civil law. Bounded by law, the modern state recognized the rights of citizens. The rule of law meant that law-governed behaviour was the rule. It is in this sense that civil society was understood as civilized society (Mamdani 1996: 14).

The key features of the structural premises of civil society cannot be carved out more clearly: individual rights, predictable rules and rule enforcement that protects citizens from the state as well as binds citizens' interactions with the state-but limited to very particular, normatively defined types of social practices and social agents.

Thus, the concept of civil society, as used in much development theory and policy, is based on certain (often circular) assumptions made with regard to both conditions as well as the effects of civil society. Especially dominant is the assumption that the 'nurturing' of civil society leads to

33 This is also emphasised by Gellner, who warns that the broad definition outlined by himself may equally well include social orders which evoke no democratic civic sphere, merely an autonomous sphere or societal segment that is not oppressed by the state. He elaborates: "Therefore, if we are to define our notion of Civil Society effectively, we must first of all distinguish it from something which may in itself be attractive or repulsive, or perhaps both, but which is radically distinct from it: the segmentary community which avoids central tyranny by firmly turning the individual into an integral part of the social sub-unit. Romantics feel nostalgia for it and modern individualists may loathe it; but what concerns us here is that, whatever our feelings for it may be, it is very, very different from our notion of Civil Society, even though it satisfies that plausible initial definition of it. It may, indeed, be pluralistic and centralization-resistant, but it does not confer on its members the kind of freedom we require and expect from Civil Society" (Gellner 1994: 36). 
the development of a bourgeois society characterised by functional differentiation, rule of law and pluralistic politics. Elliott sums up the teleology inherent in the concept:

Higher levels of education lead to greater expectations about government and greater capacity to participate in national politics. Growth of the market undermines concentrated state power. The assertion of private ownership rights stimulates demands for political rights and freedoms. Middle class and professional groups brought into existence by development lead the process of democratizing politics. The results are a shift in the balance of power between the state and society, a change in the nature of associational forms, and a redesigning of the political system along democratic lines. The predicted outcome is a civil society (Elliott 2003: 30).

However, as the previous chapters have demonstrated, these structural conditions are quite simply not given in most African countries. ${ }^{34}$ On the contrary, African societies seem to be characterised by a blurring between the public and private sphere, by public institutions shaped by both formal and informal practices, by dominance of personal and particularistic rationales rather than abstract and universal bureaucratic-legal rationale, by fragile rather than strong markets, by shadow states characterised by exclusion, dominance and coercion rather than inclusion, participation and freedom, with the types of 'classic' actors of civil society being few and fragile. With core preconditions of a conventional understanding of civil society in African political orders absent, not least the minimal requirement of the differentiation between state and society, ${ }^{35}$ the lack of empirical realities of civil society in African societies is the source of much scholarly deliberation. As, for instance, Karlström criticises with regard to African political theories, "the concept of civil society surely serves no meaningful analytical purpose if it merely identifies an absence" (Karlström 1999: 106). He goes on to argue forcefully:

Its purpose should be to enable us to identify those forces and institutions that do have some potential for producing a more productive engagement between state and society, and, ultimately, the sort of stable, legitimate, and

34 White 1996 has undertaken one of the most interesting comparative studies (here: between Singapore and Ghana), specifically analysing the structural conditions for the emergence of civil society.

35 In particular the development of capitalist modes of production and a differentiated state bureaucracy, structured along liberal democratic principles of accountability and representation. 
democratic state forms that have proven so difficult to achieve in post-colonial Africa (Karlström 1999: 106; emphasis in original). ${ }^{36}$

Here, civil society is both a social force seeking to assert and universalise certain values in political practice, such as freedom or equity or particular rights, as well as a political force seeking the redistribution or protection of certain resources vis-à-vis the state. ${ }^{37}$

However, it is hard to conceptualise the kind of forces and institutions that would shape these emancipatory and democratic spaces other than 'classic' collective actors - precisely those which are notable through their absence in African societies. As the discourse on corruption demonstrates vividly, both in the development discourse as well as in the scholarly discourse responses to the 'infernal mechanism' derive, implicitly or explicitly, from classic conceptions of the role and composition of civil society in social transformation: ${ }^{38}$ the emergence of new classes, of reciprocal networks, of voluntary organisations, of professional associations that link political order to the social basis, not just in terms of institutionalised interactions, but also and equally importantly in terms of common ethical standards and values. ${ }^{39}$

Africanists have grappled in different ways with this dilemma of absent empirical referents and the concomitant question of the analytical usefulness of the concept. Azarya addresses the conceptual and operational difficulties surrounding the term 'civil society', with the conclusion that scholars are "still faced with the need to characterize the society in some way and ask whether a legitimate civil-public sphere of action exists in contemporary African societies" (Azarya 1994: 96). Precisely because postcolonial African states' authority and legitimacy has eroded, he does not focus on the legitimacy of civil society in relationship to the state, but rather on the "characteristics of civilness based on the legitimacy attributed to the public sphere" (Azarya 1994: 96). Azarya's conceptual conclu-

36 For an early and seminal critique discussing fundamental flaws in the application of the concept of civil society to Africa see Bratton 1989. His main point of critique is that civil society as applied to Africa is an analytical concept without any empirical referents.

37 See also Gellner 1994, who posits as a necessary condition for the definition of civil society the conferral of a certain type of freedom upon its members.

38 Mamdani (1996) makes an interesting conceptual reversion by asking not how civil society shapes the state or, conversely, how civil society is marginalised by the state, but how society is ruled through the state articulation of civil society. In more Foucauldian terms, therefore, his line of inquiry is how the (specifically colonial) discourse of (un)civil society translated into social and political reality.

39 See Boltanski/Chiapello (2000) for an excellent discussion of formative features and the changing spirit of capitalism. 
sion is that civil society "may still arouse our sensitivity to a measure of recognition and societal support for collective responsibility and action" (Azarya 1994: 96). ${ }^{40}$ So, perhaps not surprisingly, we are again faced with the question of the public sphere, and issues of representation and legitimacy attached to it. ${ }^{41}$

In an effort to come to terms with these issues, Bratton defines civil society (with specific reference to the relevance for African societies) as a

public political activity that occurs in the realm between the state and the family. Although such political activity may be motivated by the quest for private advantage, it is not 'private' in the sense of being confined to the domestic or household arena, Instead, it is decidedly 'public' in two senses: It entails collective action in which individuals join to pursue shared goals, and it takes place in the institutional 'commons' that lie beyond the boundaries of the household (Bratton 1994: 56 ). ${ }^{42}$

Bratton carves out two central features: first, that civil society is bound to collective action, and second, that the articulations and interactions are public, in the sense that they are directed at a community beyond the boundaries of a particularistic group. Perhaps more constitutive, as Taylor stresses, is, thirdly, the "radically purged time consciousness: It comes when associations are placed firmly and wholly in homogenous, profane time, whether or not the higher time is negated altogether or other associations are still admitted to exist in it. Such is the case with the public sphere, and therein lies its new and (close to) unprecedented nature" (Taylor 2004: 99). ${ }^{43}$ Such are the features of a specifically modern public

40 This is a very different approach to the far more descriptive (and yet, based on her classic definition of civil society, normative) approach chosen by Chazan for instance: "State organs and social groups continually engage each other in multiple settings that are arenas of struggles for domination and accommodation. The constantly changing interactions that occur in these spaces mould and redefine the nature of state structures and social forces, generating an ongoing, mutually transforming, dynamic" (Chazan 1994: 256).

${ }^{41}$ For a seminal contribution on the "two publics in Africa" see Ekeh 1975. See also Bayart 1979 and Young 1994 for discussions on the conceptual nexus between state and civil society.

42 By the same token, he emphasises that the public nature of civic action should not be confused with politics " 'in the public sector'-in other words, in the realm of the state. As government leaders have expanded the apparatus and prerogatives of the state, they have also appropriated and distorted the term 'public' to refer exclusively to the official activities of state functionaries. When used in extreme form, the terms 'public' (referring to family life) and 'public' (meaning state actions) imply that no public space remains for occupancy by civic actors" (Bratton 1994: 56).

43 In spite of Taylor's excellent discussion of the emergence of the public sphere, he leans heavily on a Habermasian concept of a depoliticised public sphere, "a space of discussion that is self-consciously seen as being outside power. It is supposed to be listened 
sphere, a public sphere that carries within the potential for democratic politics.

Recast in post-Marxist terminology, 'public' in this sense refers to the discursive chain of equivalence which provides the terrain for articulations of identity and interests to become political, to be intelligible to other social agents, to shape and define and hegemonise the 'shared goals' and 'collective interests' - in a more Habermasian (and idealtypical deliberative) sense, civil society thus coined provides the spaces to articulate and debate shared values and interests. Civil society becomes the terrain (i.e. multiple social, cultural, political spaces, rather than a clearly delineated space) of such articulations that seek to represent their own particular aims with those of the community as a whole-albeit with reference to a very specific democratic social imaginary.

So rather than conceiving civil society as a clearly delineated sphere (or sector) separated from but related to the state, the concept of civil society carries within it manifold creative and emancipatory potential. Firstly, civil society denotes the spaces in which struggles about the meaning and the articulation of public norms and public values are carried out, the terrain in which (in the post-Marxist sense) hegemonic negotiations and deliberations are carried out. Secondly, civil society denotes the social actors which articulate these demands and struggles. And thirdly, thought together, civil society thus, potentially, becomes the very condition for linking up chains of equivalence around meanings of legitimacy, representation or indeed public interests.

Of all Africanists, Comaroff/Comaroff (1999) have been most radical and most creative in their critique and their reinvention of the concept of Civil Society—or 'The Idea', as they term it. They take above critique a step further by not only questioning the utility of a distinct sphere of civil society for African societies, but the fundamental incommensurability of the concept itself: "that the autonomy of civil society from the state, the very autonomy on which the Idea is predicated, is entirely chimerical. It, too, rests on a series of idealized separations, starting with that of political authority from private property. But this separation is, de facto, unsustainable" (Comaroff/Comaroff 1999: 24), they argue, due to the generalization of economic relationships which cut across the social and political landscape. Here, then, the deconstruction of the discourse reveals the social

to by power. But it is not itself an exercise of power" (Taylor 2004: 89). This is a premise which I do not share, premising my analysis on the essentially political constitution of society. 
and material conditions of modern societies (and its discourses on political order and civil society) and the critique of ideologically reduced concepts of African political orders lead to the same conclusion-namely that, in a very Foucauldian sense, "power dissolves the boundaries between public and private, state and society. And makes any notion of a discrete civil society, normatively and narrowly conceived, a cheerful illusion" (Comaroff/Comaroff 1999: 24). But precisely this 'cheerful illusion' has very powerful uses, for perhaps the alleged flaw of the concept, its ambiguity and diffusivity, is its major forte.

In the Comaroffs' quest for creative and meaningful perspectives of the concept of civil society, they contend that the concept historically and within the social sciences serves as a 'placeholder', a 'transitional term' that is used to create the semblance of order. More to the point, this placeholder creates the semblance of civic (and conceptual) order (Comaroff/ Comaroff 1999: 33). It is precisely in critical junctures, when social order is under stress, or when formerly meaningful social imaginaries become fragmented and insignificant, that the concept of civil society gains currency. A fundamental point they make is that 'The Idea' "becomes especially 'good to think', and to signify with, at moments when conventional connections between the political and the social, state and public, are perceived to be unravelling" (Comaroff/Comaroff 1999: 12). As such it can be critiqued for its emptiness or propensity to be filled with various ideological contents - but a far more radical and promising understanding is precisely its validation as a placeholder, its capacity to be filled with various meanings and imaginations. They argue that

increasing numbers of people presume the possibility of civil society. But it is a force less self-generating than is often supposed. And nowhere does it define a discrete or wholly autonomous sphere of social action. As we said before, its capacity to mobilize and motivate, to open up discourses of democracy and moral economy, to hold out the promise of property and political engagement lies in its very incoherence, its polysemy, its slippery opacity (Comaroff/Comaroff 1999: 24-25).

In this way, 'civil society' has all the features of an empty signifier, framing significant nodal points and enabling chains of equivalence connecting particular discourses on the 'right' kind of social order, on common objectives and values, on specific social demands and interests to be articulated and to assume representation beyond particular identities. The symbol or the idea of civil society provides the space for public, universal representations, which conceivably can be the terrain for democratic politics and articulations. What Comaroff/Comaroff seek to circumscribe theoretically 
is something they call so beautifully a 'trope of moral imagining': civil society's "capacity to open up spaces of democratizing aspiration; [...] to mandate practical experimentation in the building of new publics, new modes of association, new media of expression, new sorts of moral community, new politics" (Comaroff/Comaroff 1999: 33$)^{44}$ —in other words, civil society's capacity to create emancipatory spaces and processes. ${ }^{45}$

This rendition of civil society, very different from classically liberal concepts, carves out the similarities and relationship with the discourse of corruption as conceptualised in post-Marxist terms. The chains of equivalence enabled by the empty signifier 'civil society' intersect many nodal points enabled by the empty signifier 'corruption'. Precisely their placeholder function in times of insecurity, of blurred background structuring ideas, of conflicting normative frameworks and social practices, their capacity to inspire social imaginaries beyond particularistic interests and values lend themselves to linkages. At the same time, the social agents and forms of public communication included in this trope shape and create these social and moral imaginaries.

\section{The State of the Economy}

I now turn to the third and last sphere that has crucially produced and shaped social imaginaries, namely the economy. Expounding the relationship between the state and civil society, Giddens ponders on the historical trajectory of Western states and observes: "Civil society is the sector within which capital accumulation occurs, fuelled by the mechanisms of price, profit and investment in labour and commodity markets" (Giddens 1984: 197). Rather starkly, his argument underlines the linkage between civil society and the economy - in spite of the capitalist economic system's disconnection from particular morals and ethics, that, seemingly, are the hallmark of civil society, and which in turn makes capitalism so very powerful. ${ }^{46}$ However, just as civil society is inherently linked to the

${ }^{44}$ For a further development of such moral imaginations under the condition of global capitalism see Comaroff/Comaroff 2000.

45 As Laclau himself observes with regard to the question what kind of equivalential discourses would enable the emergence of new collective wills: "it is clear that the resulting collective will will find its anchoring point on the level of the social imaginary, and the core of that social imaginary is what we have called empty signifiers" (Laclau 20oob: 210).

46 This is no contradiction to Weber's classic study on the protestant ethics informing a specific capitalist economy, whose hallmark, as he demonstrates so inspiringly, is 
emergence of the modern state, as discussed above, the development of a market economy is inherently linked to the emergence of a civil society, i.e. a class of entrepreneurs and professionals characterized by economic autonomy. Moreover, the specific economic system produces particular systematic linkages and identities: "The (market) economy comes to constitute a sphere, that is, a way people are connected to form an interconnecting society, not only objectively but in their self-understanding" (Taylor 2004: 103). It is the economy in the narrow sense as well as the economic sphere in Taylor's sense I shall turn to now in order to explore the foundations of such social imaginaries in more detail.

The imaginary of the economy is epistemologically loaded from Marxism to Neo-liberalism, which are based on powerful if fundamentally opposing premises on the nature of the economy, and more specifically the relationship between the state, the economy and society. Concepts of the economy are central to the discourse of corruption in that they articulate specific models of economic exchange and socio-economic relations. They are formative on three different levels: firstly, models and concepts of the 'right' kind of economy inform the background ideals that are intimately intertwined with structuring ideas of state and societycompare, for instance, the conglomerate of atomised homines oeconomici that constitutes 'society' in neo-liberalism with the radical Marxist collectivism and egalitarianism of a society rid of private property. Directly and indirectly, such imaginaries are pivotal in determining what is (socially, politically or legally) considered right and what is wrong, what legitimate and what illegitimate, what is corrupt and not corrupt. Secondly, they are formative for shaping and informing power structures and power relations within a society. The allocation and distribution of material resources, the regulation and organisation of property rights, and not least the modes of production and the economic productivity of a society are decisive in determining, consolidating and producing particular social positions and relations. In this way, they frame struggles over access and allocation modes of such resources, and, by inference, social mechanisms of corruption such as described both in the political and moral economy of corruption. Thirdly, the discursive uses and appropriations of the economy are important components of the discourse on corruption, serving to explain structural causes and social practices of corruption in the scholarly

precisely its unmooring from moral and ethical foundations. For an explicit theorisation see influentially Polanyi 1957 or Boltanski/Chiaperello 2000. 
discourse as well as to justify and legitimise anti-corruption intervention strategies in the development discourse.

The structural features of the economy in Africa are specific: the private sector in most African countries has remained weak, in spite of dramatic economic regime shifts since independence, and African capital played a modest role in the struggle for independence. In the post-independence period it even waned in importance, with the public sector taking over vast areas of the economic realm, and politics either smothering or appropriating private economic initiatives. ${ }^{47}$ Partly this is a result of the centralized role of the colonial as well as post-independence state in the extraction, control and distribution of resources in many African countries discussed in the previous chapters. In post-independence African societies, especially in socialist regimes, this phenomenon lead to what Elsenhans (1981) and others have termed 'Staatsklasse', 48 a class of actors who use their public office to appropriate resources. ${ }^{49}$ The pursuit of economically unproductive behaviour and the institutional arrangements that sustain it, such as for instance personal rule described so intricately by Jackson/ Rosberg (1982) or the types of patron-client relationships explored in the last chapter, are seen to be key factors in explaining the underdevelopment of African economies.

In a study on statist Tanzania in the eighties, Bernstein/Campbell used the term 'bureaucratic bourgeoisie' to describe the factors leading to such behaviour in post-independence Africa:

Forms (and uses) of appropriation by the bureaucratic bourgeoisie do not represent accumulation in the capitalist sense (extended reproduction of capital and the development of productive forces) but predatory exaction of a pre-capitalist type ('predation') whereby goods and money are centralized

47 Underlining the political implication of the relative weakness of capital, Holmquist points out that since independence "African capital has not collectively enjoyed a prominent power position whether the regimes were civilian or military" (Holmquist 2002: 3). For further perspectives on the structural features of African economies see Collier 2006; Tangri 1999; Chazan 1994; Lemarchand 1988 or MacGaffey 1987.

48 See Elsenhans 1981.

49 In contemporary economic theory this is captured in the term 'rent-seeking', which denotes the same (unproductive) behaviour of seeking means to gain additional income, albeit unmoored from specific economic regimes. Khan has probably developed the richest theory of rent-seeking, which extends to actors in the public as well as the private sector. He elaborates the basic characteristics: "Since rents loosely represent incomes that are higher than would otherwise be obtained, they create incentives to create and maintain these rents. These activities range from bribing or even coercion at one extreme, to perfectly legal political activities such as lobbying or advertising at the other extreme. Collectively, these activities are known as rent-seeking activities" (Khan 2000: 5). 
in the control of the ruling class and redistributed to establish and expand groups of followers (Bernstein/Campbell 1985: 17).

This Marxist analysis of the underdeveloped capitalist economy, ringing rather outdated in contemporary ears, makes the relationship between political and economic order explicit, whereby the relative weakness of the economy is strongly interrelated with the relative (and specific) weakness of the state as measured in Weberian terms. A fully developed market needs - or shapes - a fully developed state. ${ }^{50}$

Moreover, the logic that sustains productive forces is one of profit, not of extraction or exchange. In this sense, capitalism is both an economic and a political concept, relating intimately to the prevailing political order. As Nyang'oro observes,

it is necessary to comprehend the sociopolitical constraint on capitalism in Africa through an analysis of the historical and social factors conditioning political adaptation, the logic of personal rule and the consequences of this for economic life. In other words, our treatment of Africa's socio-economic base $[. .$.$] is a necessary step to understand the state in contemporary Africa.$ To put it differently, politicians and bureaucrats in Africa are not inherently corrupt or 'tribalist'. Their behaviour is a response to a particular kind of a socioeconomic system in which they find themselves. That environment is not capitalist. We cannot expect a capitalist state to emerge in a society whose basic nature of political economy is essentially non-capitalist (Nyang'oro 1989: 128-129). ${ }^{51}$

This analysis, written in the historical year of 1989, illuminates the Marxist explanation for the specific types of economic relationships that prevail in Africa, economic relationships that have not (according to the development discourse: yet) been transformed into capitalist relationships penetrating the whole of society.

Two decades later, Chabal puts a different spin on ultimately the same conclusion, by emphasising the non-capitalist rationale of productive forces in contemporary Africa and explaining why class analysis is deficient:

This is not so much because classes had not consolidated in Africa but rather that even where they had begun to materialise Africans continued to largely behave according to 'traditional' social, cultural and economic logics that

50 For classic theories on capitalism (and socialism) see Weber 2004 and 1985, Polanyi 1957 and Schumpeter 1993 .

51 See Nyang'oro 1989. For a further astute analysis of the same period see also Sandbrook 1985 . 
class analysis supposed where being transcended. In this sense, it appeared that labouring within a capitalist economy did not produce classes, at least not classes that behaved like classes! (Chabal 2009: $78-79) \cdot{ }^{52}$

In spite of the dramatic Structural Adjustment Policies of the eighties, the radical ideological break after the end of the Cold War, and the spread of governance policies of the nineties, evidently fundamental features of African state-society relationships have remained unchanged. In a recent study on African political orders, Hyden also posits that neither the structural nor social conditions prerequisite for state consolidation (and the specifically capitalist market development) are given in Africa, by stating: "The double pinch that African countries face is that neither the state nor market is already fully formed or developed. Neither is in a mode of consolidation. Both are still undergoing formation" (Hyden 2006: 216) — nota bene an observation three decades after his seminal study on the economy of affection. According to these analyses, what holds true for the state and for society in Africa also holds true for the market: rather than being imbued with a distinct and ultimately dominant structuring rationale, the market's specific, profit-based rationale is merely one amongst many, permeated and transformed and appropriated by other social, political, cultural and not least economic rationales.

Although the non-consolidation of the market and the host of known characteristics of African economies-ranging from neo-patrimonial to informal to corrupt to criminal-are contingent upon local and national socio-political contexts, the international context plays an equally formative role. First of all, unlike class analysis of earlier decades, a contemporary analysis of economic development within African states cannot be separated from their dependency on foreign aid. On the one hand, multilateral and bi-lateral donors are highly influential in making and shaping domestic macro-economic and fiscal policies, with far-reaching effects on the structure and institutional framework of the economy. ${ }^{53}$ On the other hand, the distortion of domestic political accountability resulting from donor intervention leads to economic policies that are characterised by

52 In his seminal work on markets and states in Africa, Bates 1981 makes a similar argument, albeit in a more differentiated fashion. He observes that, firstly, the African bourgeoisie is quite literally spread thinly, i.e. over vast geographical and demographic spaces, hence limiting its transformative powers; secondly, its transformative power is further constrained by the prevailing social formations in former colonies, i.e. the social, economic, legal and political structures and traditions.

53 For example, see Haggard/Kaufmann 1992; van der Walle et al. 2003, Harrison 2004. 
the kind of greed and rent-seeking behaviour of African political elites that was extensively discussed in the last chapter. Moyo, a profiled Zambian economist and vocal critic of foreign aid, does not mince her words with regard to its effect: "Foreign aid props up corrupt governments-providing them with freely usable cash. These corrupt governments interfere with the rule of law, the establishment of transparent civil institutions and the protection of civil liberties, making both domestic and foreign investment in poor countries unattractive" (Moyo 2008: 49). In other words, although a large proportion of foreign aid is directed at transforming the economy and the institutional framework supporting contractual relationships and private sector development, in a perverse (but not random) twist the actual effects are precisely the opposite. ${ }^{54}$

Secondly, the effects of globalization on African economies need to be taken into account. Globalisation by definition transcends and transforms national economies, and has fundamentally affected the authority and types of national economic policies. ${ }^{55}$ The main effects are twofold. On the one hand, the technological advances characterising globalisation have had a strong accelerating effect on the corrupt siphoning off of national funds. As a direct result of the possibilities that globalised and nearly untraceable financial transactions in the eighties and nineties opened up, grand corruption in African countries and the level of stolen assets exploded. ${ }^{56}$ The stealing and stripping of national assets had, evidently, always been a problem in many post-independence African countries, but the scale has become unprecedented. The direct economic effect is the consolidation of regimes that are based on extraction and predation within globalised financial and trade systems, rather than being beholden to creating an institutional framework for production and investment.

54 For similar arguments from an economic perspective see notably Easterly 2006. For one of many critiques see the review on Dead Aid in the Oxonion under http://www .oxonianreview.org/wp/diagnosing-dongo/ (last accessed 25 March 2010). For a discerning critique of Easterly's White Man's Burden see Amartya Sen's review “The Man without a Plan", in: Foreign Affairs (March/April 2006), available under http://www.foreignaffairs .com/articles/61525/amartya-sen/the-man-without-a-plan (last accessed 25 March 2010).

55 For a seminal contribution to the effects of technological and economic transformations on political spaces see Rosenau 2003. For an interdisciplinary discussion and casestudies on standard-setting in a globalised world see the contributions in Peters/Koechlin/ Förster/Zinkernagel Fenner (eds.) 2009.

56 Moody-Stuart 1997, a prominent business-man, was one of the first to outline the mechanisms of grand, international corruption and the role of international enterprises. For a recent, highly interesting contribution dissecting the mechanisms of corruption and asset-stripping by international business in developing countries see Baker 2005. 
On the other hand, many African economies are still characterised by high dependency on primary commodities and low diversification, which means that global economic interdependencies render them more vulnerable than ever to external trends. ${ }^{57}$ As Hyden makes explicit with an intentional prod against dependency theory: "In the current global economy, African governments have little, if any, leverage and their economies are very extensively dependent on what happens to more developed and powerful economies. If African economies were ever dependent, it is now" (Hyden 2006: 226). This dependency, however, is not merely a product of the global village-it is framed by a host of internal and external factors that characterise the specific 'weakness' of African economies.

So, looking at the development of the economy since independence, African economies — and in particular the private sector-have remained relatively insignificant in terms of size, volume, productivity and diversification, although the economic and political context has changed dramatically. Subsequently, the conditions for progressive social development are still fraught, especially when incorporating broader socio-economic indicators such as GDP per capita, poverty rates, literacy or basic health indicators. These conditions run counter to the basic socio-economic configurations that are specified for prosperous societies in economic models and concepts of civil society informing this discourse, i.e. specific conditions that are more likely to result in economic innovation, political openings and empowered identities. But the kind of socio-economic transformation that was the basis of Western development, with economic productivity and civic engagement generating a virtuous interrelationship with state institutions, is all but lacking in African countries. Quite obviously, African political orders did not emanate from the "end of extraeconomic coercion, resulting in contractual relations between free and autonomous citizens that produced civilised [and, I would add: wealthy] societies" (Mamdani 1996: 14). Citizens in African are, for the most part, neither free nor autonomous. In particular, and highly relevantly for

57 For the latest statistical evidence see the annual data and report published by African Economic Outlook (http://www.africaneconomicoutlook.org/en/). Although economic growth in African countries had been on a record high for five consecutive years, in 2009 it was affected dramatically by the world Financial Crisis. The effects of the international economic crisis underlined the structural problems of many African economies, notably of the ones with a high reliance on primary exports. And as the Policy Brief of the OECD emphasises with regard to economic development in Africa: "More needs to be done to nurture an environment that is conducive to private-sector development, especially in further reducing corruption" (OECD 2009: 1-2). 
processes of social transformation, civil society is in actual fact not "the sector within which capital accumulation occurs" (Giddens 1984: 197). Accordingly, individuals (e.g. entrepreneurs) and social groups (representing collective interests) are generally not economically autonomous in a way that would enable the political articulation and representation of economically (here: capitalist) derived interests and values leading to the rule of law and responsive political structures. ${ }^{58}$ But as my quest is to identify the presence of political articulations rather than their absence, this statement on the lack of economically and hence also politically empowered collective interests in Africa will be explored in more detail in the next section.

\section{Organized Business Interests}

In Hyden's rather bland analysis of the state and economy in Africa, he outlines the classic socio-economic conditions that are necessary for a legal-rational political order to emerge:

Foremost among these is the emergence of a corporate class of independently wealthy individuals who do not have to rely on public resources to become rich. With such a group in power, the state becomes an instrument that moulds development in the image of economic reasoning. A calculative and instrumentalist approach to policy analysis and policy making emerges (Hyden 2006: 70). ${ }^{59}$

This analysis is in direct reference to Weber's theory of capitalist development (Weber 1985). Not surprisingly, the preconditions for prosperous social transformation contained in the discourse of corruption echo these points: new economic classes that are linked to the emergence of particular

58 The influence specific (here: religious) value-structures on the historically unlikely emergence of 'the capitalist spirit' is subject of a long and dense debate, sparked by Max Weber's seminal study on the spirit of capitalism (Weber 2004). For further seminal contributions see Hirschmann 1977 or Boltanski/Chiapello 2000.

59 Hyden's analysis mostly reiterates conventional knowledge on African societies, and reinforces neo-patrimonial thinking about characteristic political structures and practices: "The first is the tendency to rely on informal rather than formal institutions. In societies where face-to-face relations and primary forms of reciprocity prevail, there is no need for external rules and impersonal authorities to enforce social action. [...] The second aspect is the tendency of politics to become centrifugal; there is little respect for formal rules associated with a higher authority such as the state. The abstract nature of the system underlying the ideal of a rational-legal type of bureaucracy is ignored in favor of the locale-specific pressures and interest associated with individual communities" (Hyden 2006: 56). 
social groups, which articulate their interests and exert organised pressure on the state to protect and respect individual economic, social and political rights. To some extent, they cut across the conceptual distinctions between civil, political and economic society. ${ }^{60}$ On centre stage here are specific social groups that are economically independent from the state. These groups are characterised by several highly significant sociologically features. Firstly, their economic autonomy through income generated within the private sector, which renders them less vulnerable to pressures from the state; but at the same time the pursuit of their economic interests makes them important stakeholders in the institutional framework that the state creates for the private sector. From the nature of the economic regime right down to the spirit and letter of regulatory bodies, price and taxation policies or legal provisions, professionals and entrepreneurs have a strong interest in influencing the state's interventions.

Second, bodies representing the collective interests of professionals have historically had a seminal role in informing and shaping social values underlying merit-and issue-based social order. Their economic role goes hand in hand with a particular moral matrix, which plays a seminal role in defining Western economic and political culture. Of the classic social scientists, Durkheim (1960) was perhaps the most explicit in theorising the role of professional associations. He puts them in context of the unleashing of the economic interests in the wake of the increasing division of labour.

60 On the relationship between political, economic and civil society note Cohen/Arato, who observe that "the actors of political and economic society are directly involved with political control and economic production, which they seek to control and manage. They cannot afford to subordinate strategic and instrumental criteria to the patterns of normative integration and open-ended communication characteristic of civil society. Even the public sphere of political society rooted in parliaments involves important formal and temporal constraints of processes of communication. The political role of civil society in turn is not directly related to the control or conquest of power but to the generation of influence through the life of democratic association and unconstrained discussion in the cultural public sphere. Such a political role is inevitably diffuse and inefficient. Thus the mediating role of political society between civil society and the state is indispensible but so is the rootedness of political society in civil society. In principle, similar considerations pertain to the relationship between civil and economic society, even if, historically, under capitalism, economic society has been more successfully insulated from the influence of civil society than political society has been [...]. Nevertheless, the legalization of trade unions, collective bargaining, codetermination, and so on witness the influence of civil on economic society and allow the latter to play a mediating role between civil society and the market system" (Cohen/Arato 1994: ix-x). Interestingly, here the integrative function of political and economic society vis-à-vis civil society are underscored; an inversion of the integrative function of certain groups of civil society that Durkheim 2002 stresses, which will be discussed further down in this section. 
Rather than a social order of a utilitarian brand emerging, an order created through 'invisible hands', Durkheim sees the very same rationale of competition leading to disintegration and social pathologies. These risks, imminent to the prevailing societal order, can only be overcome by the economic actors themselves, who must create the normative standards to secure integration. More specifically, he fleshes out the role of professional associations as one of translating general norms of integration and cooperation into a particular professional culture (or 'professional moral', as Durkheim terms it.) The roles and morals of professionals are hence constructed in a reflexive turn, constituting a powerful moral authority that is endowed with the capability of countering the risks of social anomies-here in particular socio-economic disintegration and political oppression-by defining and nurturing values that in turn foster social integration through the realisation of social rights and duties. ${ }^{61}$

In other words, according to Durkheim professional associations perform key integrative functions in modern societies by expressing both social solidarity as well as undertaking effective social regulation; tasks which the vast bureaucracy of the state on the one hand and the capitalist logics of the economy on the other cannot accomplish. Durkheim thus singles out the potential of intertwined functional as well as moral features of professional associations:

Un tout autre groupe peut donc avoir la même action [integrative], pourvu qu'il ait la même cohésion. Or, en dehors de la société confessionelle, familiale, politique, il en est une autre dont il n'a pas été jusqu'à present question: c'est celle que forment, par leur association, tous les travailleurs du même ordre, tous les coopérateurs de la même fonction, c'est le groupe professionel ou la corporation (Durkheim 1990: 435$) \cdot{ }^{62}$

61 See seminal contributions by Durkheim 1960; 1990). For relevant secondary literature see Hayward 1990 or Stock 2005.

${ }^{62}$ In this sense, Emile Durkheim asserts that "the professional group might well satisfy all the conditions with laid down. On the one hand, it will not weigh heavily on industry, it is sufficiently close to the interests it will have to regulate not to repress them excessively. Furthermore, like every group formed of individuals united by ties of interests, ideas and feelings, it is capable of being a moral force for its members. If it were made a formal social organ, whereas it is as yet only a private society; if some of the rights and duties which the State is increasingly incapable of exercising and carrying out were transferred to it; if it were put in charge of administering things, industries and arts which the State cannot because of its remoteness from material things; if it had the necessary power to resolve certain conflicts, to vary the general law of society to suit particular kinds of work, gradually, through the influence that it will exercise through the rapprochement between the work of all, it will acquire the moral authority which will enable it to play the role of brake 
As Durkheim so presciently observed, professional associations, even in today's era of globalisation, remain bearers and 'multipliers' of professional identities, who are concerned with securing public (also, but not only in the sense of 'official') recognition, defining norms and standards pertaining to their professional identity, and, not least, produce an ethos that echoes beyond their own particularistic boundaries. ${ }^{63}$

Thirdly, a point particularly relevant to the development discourse, professional associations are perhaps the archetypical representatives of the educated middle class, ${ }^{64}$ heralding a socio-economic and socio-political transformation in the sense of a liberal Western society. ${ }^{65}$ In addition, they are bearers of a particular professional rationality: members of professional associations are commonly characterised by their expertise, which in turn allows them considerable work autonomy and economic security. ${ }^{66}$ It is no coincidence that Scott's typology of groups and modes of access to the political system lists professional associations as a group that has "generally easy access to the political system" (Scott 1969: 329; see also Table 3 'Corruption and Political Access' in Chapter 1, above), together with other associations and the political elite. As harbingers of structural transformation, of specifically modern organisation and representation of issue-based interests and values, and not least of valuable professional

without which economic stability would be impossible" (from "Le Socialisme", quoted in Hayward 1990: 296-297).

63 For contemporary analyses see Donor/Schneider 2000 or Lo 2005.

64 The sociological concept of middle class is as central as it is contested. Here, I use it in a very broad sense. For a classic sociological analysis of the Western middle class see sociologist Mills 1951; for a more recent contribution see Gilbert 1998.

65 Taylor intricately links the specifically modern concept of secularity to the emergence of common action purged of transcendental definitions of identity, such as characterise, for instance, traditional laws. He argues convincingly that the "crucial distinction underlying this concept of secularity can thus be related to this issue: What constitutes the association? Or otherwise put, What makes this group of people as they continue over time a common agent? Where this is something that transcends the realm of those common actions this agency engages in, the association is nonsecular. Where the constituting factor is nothing other than such common action [...] we have secularity" (Taylor 2004: 96). Evidently, professional associations fall squarely and perhaps even idealtypically into the secular category.

66 However, in his critical clarifications to class and class action Weber warned against the conceptual correlation of a particular class with an association: "Eine universelle Erscheinung ist das Herauswachsen einer Vergesellschaftung oder selbst eines Gemeinschafts-handelns aus der gemeinsamen Klassenlage keineswegs. [...] Jede Klasse kann also zwar Träger irgendeines, in unzähligen Formen möglichen "Klassenhandelns" sein, aber sie muss es nicht sein, und jedenfalls führt es zu Schiefheiten, wenn man sie mit Gemeinschaften begrifflich gleichwertig behandelt" (Weber 1985: 532-533, emphases in original). 
expertise, professional associations are key components of discourses articulating modes and interventions of social transformation-such as the discourse of corruption, which depicts an 'infernal mechanism' that can only be shattered by institutional reforms supported and initiated, inter alia, by puritanical movements, or one could also say: professional associations.

\section{Professional Associations in Africa}

A review on the literature on the role of professional associations with regard to democratic development in Africa shows that they are indeed accorded great significance as agents of social, economic and not least political change. Gros up sums the argument concisely:

Nevertheless, the advent of professional associations as a political force in African politics is a potentially significant development; it suggests that African society may be becoming less divided by ascriptive norms such as gender, age sets, and ethnicity, and more by those of professional and individual achievements. The multiplication of cross-cutting civil society institutions also may be a reflection of greater specialization and a more differentiated division of labor than has hitherto been the case. These were, in part, the social transformations that facilitated liberal democracies in the West, and there is no reason why they could not play a similar role in late twentiethcentury Africa (Gros 1998: 11).

As gleaned not least through the discussion of the scholarly discourse of corruption, influential authors underscore the potential of professional associations to push for issue-and rule-based public policies. This interest has been renewed by the effects of the political and economic liberalization of the past three decades. "Economic and political liberalization since the 1980 os has created a climate which has been conducive to new deliberative mechanisms" as Robinson (1998b: 166) expounds. He continues to cite examples from Nigeria, Ghana, Kenya and Swaziland, where the representation of business interests (more broadly than specific professional associations) have been institutionalised for the purpose of a policy dialogue with the government in various bodies. However, he qualifies this phenomenon in view of its limited outreach:

Periodic consultation restricted to government officials and a small but influential set of organized business interests is a very modest expression of enhanced political participation. In many respects this is not surprising as the principal objective of business associations is to lobby government in the hope of exacting concessions over budgetary commitments, taxation 
policies, access to credit and foreign exchange, and other issues of concern to their members [...]. Given the limited nature of societal participation in policy-making, it is difficult to estimate the developmental significance of such initiatives, even though adherents of increased participation claim that it will lead to improved policy outcomes (World Bank 1997). The skewed and exclusionary nature of policy-making that continues to prevail in much of Africa gives reason to believe that policy outcomes will reflect the interests and concerns of business elites with privileged access to the policy process, which was previously identified as a source of blockage to effective reform (Robinson 1998b: 167).

This critical remark echoes other contributions on professional associations, which view them as privileged, rent-seeking organisations rather than professional, voluntary organisations. ${ }^{67}$ Specifically, however, Robinson is sceptical whether the political spaces created by institutional reforms are sufficient to transform the exclusionary and particularistic nature of African politics towards a more inclusive nature of policymaking. "Policy-making remains the preserve of technocratic elites and policy dialogue is generally restricted to organized interests with power and resources, which provides them with privileged access to those responsible for making decisions" (Robinson 1998b: 169). This would lead to the hypothesis that business interests, if sufficiently well connected and resourced, can indeed gain substantive influence over policy making. Consequently, associations representing for instance small (and certainly informal) enterprises, which arguably constitute the greatest number of entrepreneurs in many African economies, and probably also extending to less well-connected medium-sized enterprises, are by definition excluded or struggling to gain such access to political decision-making arena.

A different aspect is problematised by Gros. Above all, he places strong emphasis on the fact that professional associations "have proven consequential for democratization" (Gros 1998: 11), citing individual examples of professional associations fighting successfully for greater civic freedoms in countries such as Cameroon or Kenya. Gros' caveat with regard to the transformative capacity of such groups also relates to modes of inclusion and exclusion, but with an explicit focus on space, not on expertise or resources:

The one weakness with African professional and civic associations is that, because they tend to be small in number, urban based and interest specific, their efficacy tends to be spatially and politically limited. [...] Unless

67 For a discussion see Donor/Schneider 2000 or Goldsmith 2002. 
urban-based professional groups link up with their rural counterparts, democratization in Africa could remain an urban elite affair, utterly unconnected to the lives of the vast majority of Africans (Gros 1998: 11). ${ }^{68}$

In other words, Gros identifies the lack of critical mass and capacity to penetrate society threatening the impact of professional associations in Africa, rather than a dominant political economy of rent-seeking.

The concerns voiced by Robinson (1998b) as well as Gros (1998) are shored up by some of the few existing empirical case-studies on the role of professional associations. For instance, Brautigam and her fellow authors (Brautigam et al. 2002) find that so-called growth-coalitions, i.e. fruitful collaborations and synergies between state and business interests (which include professional associations) are a function of the nature of the state in question, rather than the nature of the organised interests in question. Their research indicates that in the three case-studies of African societies, all of which underwent democratisation processes, the state's leadership, ideas and capacity are the most significant factors shaping patterns and processes of inclusion and cooperation. However, although their casestudies are very illuminating, their focus on business interests, rather than on the more specific professional organisations, is too broad to gain concrete further insights beyond an affirmation of the importance of the specific configuration of the state.

Taking a completely different perspective, namely from within the associations, Moore/Hamalai find that professional associations show markedly different behavioural patterns than conventionally ascribed to them. Rather than fostering professionalism and political participation, "they often act more in the interests of their own staff than in those of members. The potential for 'unproductive' rivalry and conflict between competing associations is high. The more effective associations are those not financially dependent primarily on membership fees" (Moore/Hamalai 1993: 1895). ${ }^{69}$ Just judging from these few insights on an empirical level,

\footnotetext{
68 An interesting link could be made here to Hyden's old analysis of the peasant economy and the state in Africa, who observes that the state, exerting no control over the productive relations in society, is completely disjointed from society: "[A]ppropriation by those in control of the state are made in the form of taxation and as such they are simple deductions from an already produced stock of values. These are tributary rather than productive relations and they do imply a much more limited degree of social control. In this respect, African countries are societies without a state. The latter sits suspended in 'midair' over society and is not an integral mechanism of the day-to-day productive activities of society" (Hyden 1983: 7).

69 For further studies see Moore/Hamalai 1993, Lucas 1997, or Taylor 2007.
} 
statements regarding the moral authority and or even the functional effectiveness of professional associations in fostering democratic, inclusive and productive societies are on shaky ground. There seems to be a real risk that the specifically democratic articulations of professional associations cancel each other out through competition between particular claims. Or they peter out for lack of financial and economic resources which would enable more powerful linkages across society. In other words, the claims and interests of professional articulations may not be equipped with sufficient material and symbolic resources to overcome other, more established meanings and practices. Hence, it is empirically open whether the democratic claims and demands of professional associations actually have democratising effects. Suffice to note at this point that without further empirical evidence the jury remains out with regard to concrete effects on democratic politics by professional associations.

\section{The Politics of Corruption}

In this chapter, I have sought to bring together different facets relevant to a political theory of corruption. Whereas the developmental and the academic discourses of corruption are primarily concerned with articulating the deficiency and the dysfunction of African societies and designing and implementing appropriate remedies, a political approach to corruption understands corruption as an empty signifier, a medium for the hegemonic representations of particular identities, interests and values. Corruption, theorised in this way, is inscribed with an essentially democratic moment: a communicative conveyor belt that enables the articulation and connection of particular values, needs and demands to other particular values, needs and demands. The hegemonic discourse thus becomes "a surface of inscription of a plurality of demands beyond their particularities" (Laclau 2000c: 210). This universalising potential of empty signifiers allows particular discourses to be 'fixed' in meaning whilst at the same time evoking a reference to a common universality. Precisely this linking up of chains of equivalence is the condition for the creation of public communication and the manifestation of particular struggles, a fundamentally political operation which structures social relations. As Dyrberg exclaims: "The idea is to grasp the political as a practical dimension in the ordering of the co-existence of contexts, and that this ordering of differences is an act of creation" (Dyrberg 2004: 242). So hegemonies, such as the discourses on corruption, actually create the very terrain of the political (Laclau 2000a: 
44), and politics are the structuring of these relations. ${ }^{70}$ The contextual and at the same time context-transcending articulations that corruption as an empty signifier allows is hence a necessary, if by no means sufficient condition for democratic politics.

This is precisely where the notion of civil society comes into play, which has, classically, been pivotal in denoting 'civic' public spheres and modes of communication, where shared democratic values and norms are deliberated. The reinterpretation of civil society as a canvas for social imaginaries illuminates its position in the chain of equivalence in which corruption acts as an empty signifier. Importantly, civil society is endowed with the potential to be the terrain in which social actors produce and shape social imaginaries, articulate specific political demands and engage in negotiations, deliberations, conflicts and struggles. In other words, by making hegemonic articulations of corruption by specific social actors a potential vehicle of emancipation, this political theorisation of corruption has transcended the reduction of corruption to a symptom of institutional dysfunction or functional disorder. Again, the potentially creative, pluralistic moment of hegemonic representations is underscored.

But although this approach has opened up the theoretical means to conceptualise corruption in a potentially emancipatory way, the social actors that articulate their interests by seeking to fill corruption with particular meanings and demands still remain rather abstract. A recourse to the development and scholarly discourse on corruption also fails, as significant insights are either absent or refer to a diffuse macro-level. A key objective of this exploration, however, is to understand the microprocesses of such hegemonic articulations, for which concrete groups and actors need to be identified. This line of thought brings us to the economy, more precisely: to the relationship between social change, civil society and the economy. To explore loci and actors of social change of a democratic nature, the terrain of civil society needs to be filled with specific economic features. This is important for both conceptual and practical reasons. The economy is both a symbol as well as a field of economic, political and social differentials. Economic relations and related imaginaries of the 'right' society are formative for social actors that historically have been pivotal to shaping social values, rationalities and practices that underpin

70 See also Laclau 2000a, b, and c. For an elaborate discussion of the relationship between the political and politics in Laclau's and Mouffe's discourse analysis see Dyrberg 2004 . 
not just democratic but also productive societies. On the other hand, the discussion on structural features of the African economy concluded that African economies-and societies-are characterised by a significant lack: a lack of capitalist relations that have managed to transform and penetrate both state and society to the extent of Western societies. ${ }^{71}$ This ties in with much of the scholarly discourse on corruption, which identifies the lack of (the historically intermeshed) legal-bureaucratic rationale as one key feature of African societies and political orders, leading to varying degrees of hybrid, oscillating or fused rationalities and exchange mechanisms of a negative connotation ('poor', 'corrupt', 'criminal', 'neopatrimonial', 'unstable', etc.).

The explorations of this chapter do not stop short at this insight. Although I recognise the structural features of African societies identified at a macro-level, my hypothesis remains that micro-processes of social and political change are underexplored and under-conceptualised; hence the recourse to key theoretical insights of post-Marxist political theory. Doggedly, the search for social actors with emancipatory potential is continued by zooming in on classic agents of social change. These actors need to meet both social as well as economic requirements endowing them with the capability of raising their voice-in post-Marxist terms: of articulating particular representations with both hegemonising as well as emancipatory potential. Professional associations fully meet this requirement: firstly, they have historically embodied important moral as well as regulatory functions; secondly, their members arguably occupy a privileged position in the social field, certainly in terms of material and symbolic capital, and on this basis act both as indicator as well as actors of socioeconomic transformation; and thirdly, significant for our purposes, 'corruption' and all that it stands for is conceivably a highly politicised topic that lends itself to be filled with their own, particular interests.

This takes us to the second part of the book, in which an empirical inquiry into professional associations in Tanzania will be undertaken. The working hypothesis is that in spite of the structural configurations of African societies and the limited number and outreach of professional associations, they are endowed with the wherewithal to engage in the public sphere. More to the point, their own professional interests and values lend

71 Of course, this also ties in with Polanyi's seminal insight that capitalism is in fact a historical anomaly, especially the degree to which economic relations are disembedded from social relations (Polanyi 1957). 
themselves to be linked up with key statements of the development discourse, especially with regard to institutional quality and the creation and legal protection of economic spaces. In this context, 'corruption' seems an ideal signifier in their struggles to be recognised and heard, providing as it does powerful nodal points with domestic political discourses as well as international development discourses relating to a 'universal', encompassing order.

These issues will be fleshed out empirically in the second part of this study. However, what needs to be stressed here is that the choice of actors is deliberately conservative: professional associations are actors that do not herald new morals or radical social imaginaries. What makes them attractive for our analytic purposes is that they are actors precisely in the mould of the development and scholarly discourse(s) of corruption. This renders the premises of the discourse of corruption legible to the political theory of corruption developed here. The question is whether, on an empirical micro-level, under the specific power relations analysed in African societies these struggles do indeed lead to public articulations shaping more inclusive, contingent and better (in a technical and functional sense) rules and institutions than are currently found in most African states. Indeed, the question is whether and how it enables democratic politics in the context of African societies. 